\title{
Women Directors and Cost of Debt
}

\author{
Dominic Hu Khie Yeen* and Azlan Ali \\ School of Business and Management, \\ University College of Technology Sarawak \\ *Corresponding Author: dkyhu@ pilley.edu.my
}

\begin{abstract}
Calling for a gender-balanced board has become a global trend since a few decades ago. Malaysia envisions to have at least 30 percent of women directors in board of directors by 2020 and making mandatory for large listed firms to take the lead since 2017 . On the other hand, bank loan is one of the main sources of finance to Malaysia listed firms. On top of that, cost of debt plays a significant role when firms considering debt finance. Fortunately, it can be reduced through corporate governance mechanism, namely a gender-balanced board. Nevertheless, the empirical evidences on the relationship between gender-balanced board and cost of debt based on emerging markets including Malaysia remaining scarce up to date warrant a study. Therefore, a study to determine the relationship between women directors and cost of debt in Malaysia is proposed in respond to the callings. There are a few implications of the proposed study. Firstly, it contributes to the hot debates on how women directors contribute to the board. Secondly, it contributes to the further understanding of different context's outcome, specifically both developed and emerging market. Practically, it sheds light to the regulators and policy makers in setting future corporate governance guideline. Besides that, it also provides insight to nomination committee in recruiting new board member. Lastly, it can become an additional reference to the potential investor when making their investment decision.
\end{abstract}

Keywords: Agency Theory, Board of Directors, Corporate Governance, Cost of Debt, Women Directors

\section{Introduction}

Board of directors (BOD) is the top management to devise, implement and review the strategic direction of a firm (Fama \& Jensen, 1983). BOD diversity is a subset of board composition. It is one of the key attributes which determine firms' performance. On top of that, behavioral theory supports a well diverse BOD (Cyert \& March, 1963). It is because homogeneous BOD may be a hinderance to innovation due to preference of conformity and group think (Miller \& Triana, 2009). On the other hand, heterogenous BOD contributed wider knowledge which result in more innovation ideas and better quality decisions (Hoffman, 1959; Joshi \& Roh, 2009). Nevertheless, the impact of BOD diversity is inconclusive. Some researchers found a diversified BOD reduced the effectiveness and efficiency of the BOD 's decision making process seeing more disputes, miscommunication and delayed decision making (Carpenter, 2002; Smith, Smith, \& Verner, 2005) due to the need to reconciled different opinions and voices coming from members with different background and culture (Carter, D'Souza, Simkins, \& Simpson, 2010; Miller, Burke, \& Glick, 1998). 
Past literature studies the effect of BOD diversity based on various demographic characteristics such like ethnic (Abdullah \& Ismail, 2016; Abdullah, Maruhun, Tarmizi, \& Rahman, 2018; Abdul, Madah Marzuki, Jaafar, \& Masron, 2018; Gul, Munir, \& Zhang, 2016), gender (Abdullah \& Ismail, 2016; Authors, 2015; Badru, Ahmad-Zaluki, \& Wan-Hussin, 2019; Hussain, Rigoni, \& Orij, 2018; Jubilee, Khong, \& Hung, 2018; López-Delgado \& Diéguez-Soto, 2018; Low, Roberts, \& Whiting, 2015; Omar \& Amran, 2017; Poletti-Hughes \& Briano-Turrent, 2019; Sheela, Je-Yen, \& Rajangam, 2016; Usman, Farooq, Zhang, Makki, \& Khan, 2019), religion (Authors, 2017; Čornanič, Novák, \& Šarapatka, 2018) and others. Among them, gender-balanced board brought alternative viewpoints (Zahra \& Pearce, 1989), mitigated the shortcoming of corporate governance (Gul, Srinidhi, \& Ng, 2011), reduced financial reporting mistake and fraud (Wahid, 2018), improved firm 's performance (Dezso \& Ross, 2012) and contributed to the strategic direction (T. Miller \& Triana, 2009).

All of these are mainly due to the fact that gender do influence decision making process in corporate world as men and women are different in their choice and preferences from both economist and psychologists' point of view (Barber \& Odean, 2001; Byrnes, Miller, \& Schafer, 1999; Eckel \& Grossman, 2008; Rossi, Hu, \& Foley, 2017). Women directors contributed to the board in various ways (Hoobler, Masterson, Nkomo, \& Michel, 2016). They bring various expertise and experiences than men do. (Hillman, Cannella, \& Paetzold, 2000; Hillman, Shropshire, \& Cannella, 2007), reconcile the conflict of interest between board members (Fama \& Jensen, 1983), understand the market better and leading to better decision making (Carter, Simkins, \& Simpson, 2003).

From the stakeholder theory perspective, BOD represents all stakeholders including employee, supplier, customer, lender, regulator, community and whichever party has an interest in the firm. It should no longer solely be accountable to shareholders who are mainly interested in financial information of the firms (Finegold, Benson, \& Hecht, 2007). Therefore, BOD portfolio should meet such demands from all stakeholders (Huse, 2005). Thus, introduction of female directors is crucial as they are more alert of non-financial impact such like sustainability (Labelle, Francoeur, \& Lakhal, 2015), social and environmental issues (Williams, 2003) and public disclosure. (Gul et al., 2011) They should help in winning the heart of these stakeholders (Bear, Rahman, \& Post, 2010; Branco \& Rodrigues, 2008) and eventually help the firm to access the valuable resources and creating long term sustainable contribution.

In the past, women directors needed to put in extra effort to be accepted into the board and worked with their peers especially in masculine firms (Eagly \& Carli, 2003). They were also pressured to follow their leader rather than challenged the authority and were weak monitors (Usman, Farooq, Zhang, Makki, \& Khan, 2019).

Since a few decades ago, calling for a gender-balanced board has become a global especially in those developed market. For example, there are 14 countries that are practicing a gender-balanced board and 16 countries' code of corporate governance encourage it for listed firms (Terjesen, Couto, \& Francisco, 2016). Malaysia is in the former which envisions to have at least $30 \%$ of women directors on the board by 2020 making mandatory for large listed firms to take the lead effective since 2017 in view of their significant socioeconomic impact to the country (Bursa Malaysia, 2017).

On the other hand, Risk preference of a firm determined its competitiveness in the industry (Sila, Gonzalez, \& Hagendorff, 2016) while indebtedness impacted on its productivity (G. Anderson \& Raissi, 2018) and economic growth (Mika \& Zumer, 2017). 
Generally, firms preferred to utilize internal fund to meet investment needs and debt financing over equity financing when external funding was necessary (Myers \& Majluf, 1984). Actually, debt or equity financing to meet investment needs is always a question of management deliberation (Ghouma, Ben-Nasr, \& Yan, 2018). Pecking order theory suggests debt should take priority over equity financing as it is relatively cheaper and enables firms to expand and grow beyond its existing scale which may be restricted by organic accumulated internal generated fund (Frank \& Goyal, 2003). On the other hand, trade-off theory raises the concern over cost of debt as one of the main considerations when firms making its financial decision to balance the risk associated with indebtedness, for example restricted covenant, extra disclosure effort and bankruptcy the worst (G. Rajan \& Luigi, 1995; Graham, 1996). Despite the arguments aforementioned, bank loan remained as one of the main sources of finance to Malaysia listed firms (Fraser, Zhang, \& Derashid, 2006).

Up to date, the influence of women directors towards firm performance has been studied widely in the past (Chapple \& Humphrey, 2004; Hewa Wellalage, 2013) with mixed results (Post \& Byron, 2015). Majority of the evidences showed gender diversity was significant positively associated with firm 's performance (Adams \& Ferreira, 2009; Campbell \& Vera, 2010; Francoeur, Labelle, \& Sinclair-Desgagné, 2008; Green \& Homroy, 2018; Low et al., 2015; Murray, 1989; Post \& Byron, 2015; Singh, Terjesen, \& Vinnicombe, 2008; N. Smith, Smith, \& Verner, 2006; Solakoglu \& Demir, 2016) and value (Campbell \& Mínguez-Vera, 2008; Carter et al., 2003; Erhardt, Werbel, \& Shrader, 2003; Jubilee et al., 2018; Perryman, Fernando, \& Tripathy, 2016; Scholtz \& Kieviet, 2018) while some evidences showed that there were either small (Konrad, Kramer, \& Erkut, 2008), insignificant (Carter et al., 2010; Shukeri, Shin, \& Shaari, 2012), none (Pletzer, Nikolova, Kedzior, \& Voelpel, 2015) mixed results (Shamsul N. Abdullah, Ismail, \& Nachum, 2016) or even negative (Adams \& Ferreira, 2009; Ahern \& Dittmar, 2012) relationship between women directors and firms' performance.

Nevertheless, the relationship between women directors and cost of debt is inconclusive due to limited empirical evidences up to date. Among them were cost of debt decrease (Ghouma et al., 2018; Usman, Farooq, Zhang, Makki, \& Sun, 2019) despite some studies argued that there was no significant relationship associated (R. C. Anderson, Mansi, \& Reeb, 2004; Luo, Huang, Li, \& Lin, 2018).

Despite a lot of studies being carried out to evaluate the relationship between women directors and cost of debt in developed markets, the relevant studies which based on emerging market is still scarce up to date. Past studies suggested that outcome between developed and emerging market might not be the same due to number of institutional issues (Fan, Wei, \& Xu, 2011; Tee, 2018) including less developed legal system and lower information quality (Liu \& Lu, 2007), higher information asymmetry (Akhtar, 2017) and unique culture (Costa, Terracciano, \& McCrae, 2001) which may lead to the organization and behavior differences. Meanwhile, there are callings from previous literatures to extend the cost of debt research in different context (Hashim \& Amrah, 2016), specifically Malaysia. Therefore, a study to determine the relationship between women directors and cost of debt in Malaysia is proposed.

\section{Literature Review}

\section{Agency Theory}


The fundamental principle of Agency Theory is the conflict of interest between the owner, namely the shareholders and the agents, namely the management of the firm. shareholders looking for wealth maximation whereas management focus on personal wealth, job security as well as their status (Jensen, 1976).

The conflict of interest may result in the managerial opportunism threat. For example, management might entrench themselves by entering into selected contracts which they are familiar with rather than benefits the firms the most to secure their office (Shleifer, AndreiVishny, 1989). They might also be involved in earning management in real activities manipulation such like perform last minute promotion to increase turnover or overproduction to reduce cost of sales and postpone discretionary expenditures to present a better financial performance (Roychowdhury, 2006), initiate significant corporate events such like Initial Public Offering (IPO) (S. H. Teoh, Welch, \& Wong, 1998) or Seasonal Equity Offering (SEO) (S. S. H. Teoh, Welch, \& Wong, 1998) and Mergers and Acquisitions (M\&A) (Erickson \& Wang, 1999). Therefore, debt providers consider such threats and the associated potential risk of default when issue debt by adjusting the cost of debt to reflect the risk embedded (Anderson, Mansi, \& Reeb, 2003; Lin, Ma, Malatesta, \& Xuan, 2011; Ma, Ma, \& Tian, 2017).

Nevertheless, it is believed that agency cost might be reduced and even avoided if firms consolidate its ownership and management, for example in family firm (Chrisman, Chua, \& Lits, 2004; Demsetz \& Lehn, 1985; Fama \& Jensen, 1983; Jensen, 1976) since the alignment of interest between the shareholders and management is much higher (Anderson et al., 2003; Ang, Cole, \& Lin, 2000; Daily \& Dollinger, 1992).

Besides that, Corporate governance mechanisms also reduced the agency cost (Ghouma et al., 2018; Hashim \& Amrah, 2016; Klock, Mansi, \& Maxwell, 2005) including cost of debt (Anderson et al., 2004; Bhojraj \& Sengupta, 2003; Claessens \& Yurtoglu, 2013; Pittman \& Fortin, 2004). Among them, BOD's characteristic significant associated with cost of debt (Anderson et al., 2004). Board diversity as one of the corporate governance mechanisms results in better monitoring (Bhojraj \& Sengupta, 2003) with critical questions that might not be asked if the BOD are possessing same attributes (Carter et al., 2003) and better disclosure to mitigate information asymmetry problem (Bhojraj \& Sengupta, 2003; Ghouma et al., 2018).

\section{Women Directors}

Study on gender-balanced board is gaining traction recently as more and more studies showed women directors complement BOD in numerous ways. Women in nature play their role more serious (Schmitt, Realo, Voracek, \& Allik, 2008), for instance better prepared (Pathan \& Faff, 2013), attended more meeting (Adams \& Ferreira, 2009) often assessed board function (Nielsen \& Huse, 2010) and promoted higher ethical standard (Terjesen, Sealy, \& Singh, 2009). All of these attributes reduced agency cost (RegueraAlvarado, de Fuentes, \& Laffarga, 2017), brought better governance (Adams \& Ferreira, 2009; Singh \& Vinnicombe, 2004), tougher monitoring (Adams \& Ferreira, 2009; Konrad et al., 2008) and improved earning quality eventually (Srinidhi, Gul, \& Tsui, 2011). As a result, alternative monitoring approach including indebtedness could be less necessary to be employed as a control mechanism as suggested by free cash-flow theory since there is existence of strong monitor function by women directors.

Notwithstanding the aforementioned benefits of a gender-balanced board, the benefits of having woman director on board depends on the existence of "critical mass" situation (Konrad et al., 2008). In other words, there should be adequate number 
of female directors in board before their opinions can be genuinely noted and appreciated (Torchia, Calabrò, \& Huse, 2011). Besides that, the culture of individual countries is also one of the determinant of the women 's performance (Terjesen \& Singh, 2008).

\section{Cost of Debt}

Apart from that, cost of debt also associated negatively with information asymmetry problem. It is due to the external investors may perceive controlling shareholders are likely to expropriate them when the corporate transparency is low (Anderson, Duru, \& Reeb, 2009; Fan \& Wong, 2002; Leuz, Nanda, \& Wysocki, 2003) especially in weaker institution environment (Dyck \& Zingales, 2004; Porta, Lopez-de-silanes, Shleifer, \& Vishny, 2000). The transparency problem went lower when the it can be overcome through reducing the agency cost (Bhojraj \& Sengupta, 2003; Sengupta Partha, 1998) and increase the earning quality (Francis, LaFond, Olsson, \& Schipper, 2005) by transparent disclosure especially in accounting and financial information (Bushman \& Smith, 2001; Pittman \& Fortin, 2004; Smith \& Warner, 1979). In summary, cost of debt reduced when conflict of interest be alleviated through efficient debt contract when there is a transparent habit shod by the borrower (Armstrong, Guay, \& Weber, 2010). It is even more pronounced in the country when the formal institution is weak whereas informal contracts which consist of relationship developed over years (Armstrong et al., 2010). On the other hand, cost of debt goes up when corporate opacity has taken place (Ma et al., 2017).

\section{Women Directors and Cost of Debt}

A gender-balanced board is one of the effective solutions to tackle with information asymmetry problem once again. It is because women directors possess higher ethical value than man. For example, they are less likely to be involved in bribery and corruption compared to their male peers (Swamy, Knack, Lee, \& Azfar, 2001). Therefore, it should result in more transparency disclosure and higher earning quality (Wahid, 2018).

\section{Conclusion}

Women directors contributed to the BOD in various ways including strengthen monitor, promoted higher transparency in information disclosure, cultivated ethical value among the BOD. All of these contributions helped in alleviating agency cost which arise between shareholders and the management as well as leading to lower cost of debt as a result of debt providers' confidence been regained.

Nevertheless, there are limited empirical evidences on the relationship between women directors and cost of debt especially in emerging market including Malaysia. This constitute a research gap which need to be addressed as past studies suggested that outcome between developed and emerging market might not be the same due to number of institutional issues (Fan et al., 2011; Tee, 2018) which may lead to the organization and behaviour differences. On top of that, the study is also going to respond to the callings from past literatures to extend the cost of debt research in different context (Hashim \& Amrah, 2016).

The implications of such study are as follows. Firstly, it contributes to the hot debates on how women directors contribute to the board since they play a significant role in terms of governance (Carter et al., 2010; Farrell \& Hersch, 2005) and provide empirical evidence so it may serve as a basis or references for the future research. 
Secondly, it contributes to the further understanding of different context's outcome, specifically cost of debt between developed and emerging market.

Practically, it sheds light to the regulators and policy makers in setting future Corporate Governance guideline. For example, future guideline may emphasise the necessity of a gender-balance board to encourage more women to be on BOD for better firm performance and country's economy growth. Besides that, it also provides insight to nomination committee in recruiting new board member for the best interest of the firm. Lastly, it can become an additional reference to the potential investors when making their investment decision.

\section{Reference}

Abdullah, Shamsul N., Ismail, K. N. I. K., \& Nachum, L. (2016). Does having women on boards create value? The impact of societal perceptions and corporate governance in emerging markets. Strategic Management Journal, 37(3), 466-476. https://doi.org/10.1002/smj.2352

Abdullah, Shamsul Nahar, \& Ismail, K. N. I. K. (2016). Women directors, family ownership and earnings management in Malaysia. Asian Review of Accounting, 24(4), 525-550.

Abdullah, W. R. W., Maruhun, E. N. S., Tarmizi, M. A., \& Rahman, L. A. (2018). Mitigating Earnings Management: Adoption of IFRS and Corporate Governance Practices in Malaysia. International Journal of Academic Research in Business and Social Sciences, 8(2), 760-772. https://doi.org/10.6007/IJARBSS/v8-i2/3983

Adams, R. B., \& Ferreira, D. (2009). Women in the boardroom and their impact on governance and performance. Journal of Financial Economics, 94(2), 291-309. https://doi.org/10.1016/j.jfineco.2008.10.007

Ahern, K. R., \& Dittmar, A. K. (2012). The changing of the boards: The impact on firm valuation of mandated female board representation. Quarterly Journal of Economics, 127(1), 137-197. https://doi.org/10.1093/qje/qjr049

Akhtar, S. (2017). Capital structure of multinational and domestic corporations - a crosscountry comparison. Accounting \& Finance, 57(2), 319-349. https://doi.org/10.1111/acfi.12135

Anderson, G., \& Raissi, M. (2018). Corporate Indebtedness and Low Productivity Growth of Italian Firms (33 No. 18). IMF Working Papers. https://doi.org/10.5089/9781484343265.001

Anderson, R. C., Duru, A., \& Reeb, D. M. (2009). Founders, heirs, and corporate opacity in the United States. Journal of Financial Economics, 92(2), 205-222. https://doi.org/10.1016/j.jfineco.2008.04.006

Anderson, R. C., Mansi, S. A., \& Reeb, D. M. (2003). Founding family ownership and the agency cost of debt. Journal of Financial Economics, 68(2), 263-285. https://doi.org/10.1016/S0304-405X(03)00067-9

Anderson, R. C., Mansi, S. A., \& Reeb, D. M. (2004). Board characteristics, accounting report integrity, and the cost of debt. Journal of Accounting and Economics, 37(3), 315-342. https://doi.org/10.1016/j.jacceco.2004.01.004

Ang, J. S., Cole, R. A., \& Lin, J. W. U. H. (2000). Agency Costs and Ownership Structure. The Journal of Finance, Vol. 55(1), 81-106. https://doi.org/10.1111/0022-1082.00201

Armstrong, C. S., Guay, W. R., \& Weber, J. P. (2010). The role of information and 
financial reporting in corporate governance and debt contracting. Journal of Accounting and Economics, 50(2-3), 179-234. https://doi.org/10.1016/j.jacceco.2010.10.001

Authors, F. (2015). Article information: Corporate Governance and Carbon Transparency : Australian Experience.

Authors, F. (2017). Islamic ethical values of corporate top leadership and real earnings management Article information: Islamic Ethical Values of Corporate Top Leadership and Real Earnings Management.

Badru, B. O., Ahmad-Zaluki, N. A., \& Wan-Hussin, W. N. (2019). Women on corporate boards and allocation of capital raised through IPOs. Management Decision, 57(3), 547-568. https://doi.org/10.1108/MD-11-2017-1121

Barber, B. M., \& Odean, T. (2001). Boys will be boys: Gender, overconfidence, and common stock investment. Quarterly Journal of Economics, 116(1), 261-292. https://doi.org/10.1162/003355301556400

Bear, S., Rahman, N., \& Post, C. (2010). The Impact of Board Diversity and Gender Composition on Corporate Social Responsibility and Firm Reputation. Journal of Business Ethics, 97(2), 207-221. https://doi.org/10.1007/s10551-010-0505-2

Bhojraj, S., \& Sengupta, P. (2003). Effect of Corporate Governance on Bond Ratings and Yields: The Role of Institutional Investors and Outside Directors. The Journal of Business, 76(3), 455-475. https://doi.org/10.2469/dig.v34.n2.1409

Branco, M. C., \& Rodrigues, L. L. (2008). Factors influencing social responsibility disclosure by Portuguese companies. Journal of Business Ethics, 83(4), 685-701. https://doi.org/10.1007/s10551-007-9658-z

Bursa Malaysia. (2017). Corporate Governance Guide - 3rd Edition. Bursa Malaysia Berhad. Kuala Lumpur.

Bushman, R. M., \& Smith, A. J. (2001). Financial accounting information and corporate governance. Journal of Accounting and Economics, 32(1-3), 237-333. https://doi.org/10.1016/S0165-4101(01)00027-1

Byrnes, J. P., Miller, D. C., \& Schafer, W. D. (1999). Gender differences in risk taking: A meta-analysis. Psychological Bulletin, 125(3), 367-383. https://doi.org/10.1037/0033-2909.125.3.367

Campbell, K., \& Mínguez-Vera, A. (2008). Gender diversity in the boardroom and firm financial performance. Journal of Business Ethics, 83(3), 435-451. https://doi.org/10.1007/s10551-007-9630-y

Campbell, K., \& Vera, A. M. (2010). Female board appointments and firm valuation: Short and long-term effects. Journal of Management and Governance, 14(1), 3759. https://doi.org/10.1007/s10997-009-9092-y

Carpenter, M. A. (2002). The implications of strategy and social context for the relationship between top management team heterogeneity and firm performance. Strategic Management Journal, 23(3), 275-284. https://doi.org/10.1002/smj.226

Carter, D. A., D’Souza, F., Simkins, B. J., \& Simpson, W. G. (2010). The gender and ethnic diversity of US boards and board committees and firm financial performance. Corporate Governance: An International Review, 18(5), 396-414. https://doi.org/10.1111/j.1467-8683.2010.00809.x

Carter, D. A., Simkins, B. J., \& Simpson, W. G. (2003). Corporate governance, board diversity, and firm value. Financial Review. https://doi.org/10.1111/15406288.00034

Chapple, L., \& Humphrey, J. E. (2004). Does board gender diversity have a financial 
impact? Evidence using stock portfolio performance. Journal of Business Ethics, 12(4), 479-. https://doi.org/10.1007/s10551-013-1785-0

Chrisman, J. J., CHua, J. H., \& Lits, R. A. (2004). Comparing the Agency Costs of Family and Non-Family Firms: Conceptual Issues and Exploratory Evidence. Entrepreneurship: Theory and Practice, 28(4), 335-354. https://doi.org/10.1111/j.1540-6520.2004.00049.x?journalCode=etpb

Claessens, S., \& Yurtoglu, B. B. (2013). Corporate governance in emerging markets: A survey. Emerging Markets Review. Elsevier B.V. https://doi.org/10.1016/j.ememar.2012.03.002

Čornanič, A., Novák, J., \& Šarapatka, J. (2018). Religion, corporate governance, and executive compensation. Finance a Uver - Czech Journal of Economics and Finance, 68(1), 34-70.

Costa, P. T., Terracciano, A., \& McCrae, R. R. (2001). Gender differences in personality traits across cultures: Robust and surprising findings. Journal of Personality and Social Psychology, 81(2), 322-331. https://doi.org/10.1037/0022-3514.81.2.322

Cyert, R. M., \& March, J. . (1963). A behavioral theory of the firm.

Daily, C. M., \& Dollinger, M. J. (1992). An Empirical Examination of Ownership Structure in Family and Professionally Managed Firms. Family Business Review. https://doi.org/10.1111/j.1741-6248.1992.00117.x

Demsetz, H., \& Lehn, K. (1985). The structure of corporate ownership: Causes and consequences. Journal of Political Economy, 93(6), 1155-1177. https://doi.org/10.4324/9780203878460

Dezso, C. L., \& Ross, D. G. (2012). Does Female Representation in Top Management Improve Firm Performance? A Panel Data Investigation. Strategic Management Journal. https://doi.org/10.1002/smj

Dyck, A., \& Zingales, L. (2004). Private Benefits of Control: An International Comparison. The Journal of Finance, 59(2), 537-600. Retrieved from https://www.jstor.org/stable/3694907?seq=1\#page_scan_tab_contents

Eagly, A. H., \& Carli, L. L. (2003). The female leadership advantage: An evaluation of the evidence. Leadership Quarterly, 14(6), 807-834. https://doi.org/10.1016/j.leaqua.2003.09.004

Eckel, C. C., \& Grossman, P. J. (2008). Chapter 113 Men, Women and Risk Aversion: Experimental Evidence. Handbook of Experimental Economics Results, 1(C), 1061-1073. https://doi.org/10.1016/S1574-0722(07)00113-8

Effiezal Aswadi Abdul, W., Madah Marzuki, M., Jaafar, S. B., \& Masron, T. A. (2018). Board diversity and total directors' remuneration: evidence from an emerging market. Pacific Accounting Review, 30(2), 243-272. https://doi.org/10.1108/PAR02-2016-0021

Erhardt, N. L., Werbel, J. D., \& Shrader, C. B. (2003). Board of Director Diversity and Firm Financial Performance. Corporate Governance, 11(2), 102-111. https://doi.org/10.1111/1467-8683.00011

Erickson, M., \& Wang, S. W. (1999). Earnings management by acquiring firms in stock for stock mergers. Journal of Accounting and Economics, 27(2), 149-176. https://doi.org/10.1016/S0165-4101(99)00008-7

Fama, E. F., \& Jensen, M. C. (1983). Separation of Ownership and Control Separation of Ownership and Control. Journal of Law and Economics. https://doi.org/10.1086/467037

Fan, J. P. H., Wei, K. C. J., \& Xu, X. (2011). Corporate finance and governance in 
emerging markets: A selective review and an agenda for future research. Journal of Corporate $\quad$ Finance, 17(2), 207-214. https://doi.org/10.1016/j.jcorpfin.2010.12.001

Fan, J. P. H., \& Wong, T. J. (2002). Corporate ownership structure and the informativeness of accounting earnings in East Asia. Journal of Accounting and Economics, 33(3), 401-425. https://doi.org/10.1016/S0165-4101(02)00047-2

Farrell, K. A., \& Hersch, P. L. (2005). Additions to corporate boards: The effect of gender. Journal of Corporate Finance, 11(1-2), 85-106. https://doi.org/10.1016/j.jcorpfin.2003.12.001

Finegold, D., Benson, G. S., \& Hecht, D. (2007). Corporate boards and company performance: Review of research in light of recent reforms. Corporate Governance: An International Review, 15(5), 865-878. https://doi.org/10.1111/j.14678683.2007.00602.x

Francis, J., LaFond, R., Olsson, P., \& Schipper, K. (2005). The market pricing of accruals quality. Journal of Accounting and Economics, 39(2), 295-327. https://doi.org/10.1016/j.jacceco.2004.06.003

Francoeur, C., Labelle, R., \& Sinclair-Desgagné, B. (2008). Gender diversity in corporate governance and top management. Journal of Business Ethics, 81(1), 8395. https://doi.org/10.1007/s10551-007-9482-5

Frank, M. Z., \& Goyal, V. K. (2003). Testing the pecking order theory of capital structure. Journal of Financial Economics (Vol. 67). https://doi.org/10.1016/S0304-405X(02)00252-0

Fraser, D. R., Zhang, H., \& Derashid, C. (2006). Capital structure and political patronage: The case of Malaysia. Journal of Banking and Finance, 30(4), 1291-1308. https://doi.org/10.1016/j.jbankfin.2005.05.008

G. Rajan, R., \& Luigi, Z. (1995). What Do We Know about Capital Structure? Some Evidence from International Data. The Journal of Finance, 50(5), 1421-1460. Retrieved from https://www.jstor.org/stable/2329322?seq=1/analyze

Ghouma, H., Ben-Nasr, H., \& Yan, R. (2018). Corporate governance and cost of debt financing: Empirical evidence from Canada. Quarterly Review of Economics and Finance, 67, 138-148. https://doi.org/10.1016/j.qref.2017.06.004

Graham, J. K. (1996). Debt and the marginal tax rate. Journal of Financial Economics, 41(1), 41-73. $\quad$ Retrieved from https://www.sciencedirect.com/science/article/pii/0304405X9500857B

Green, C. P., \& Homroy, S. (2018). Female directors, board committees and firm performance. European Economic Review, 102(1), 19-38. https://doi.org/10.1016/j.euroecorev.2017.12.003

Gul, F. A., Munir, S., \& Zhang, L. (2016). Ethnicity, politics and firm performance: Evidence from Malaysia. Pacific Basin Finance Journal, 40, 115-129. https://doi.org/10.1016/j.pacfin.2016.10.005

Gul, F. A., Srinidhi, B., \& Ng, A. C. (2011). Does board gender diversity improve the informativeness of stock prices? Journal of Accounting and Economics, 51(3), 314-338. https://doi.org/10.1016/j.jacceco.2011.01.005

Hashim, H. A., \& Amrah, M. (2016). Corporate governance mechanisms and cost of debt. Managerial Auditing Journal, 31(3), 314-336. https://doi.org/10.1108/maj12-2014-1139

Hewa Wellalage, N. (2013). Women on Board, Firm Financial Performance and Agency Costs. Ssrn, 113-127. https://doi.org/10.2139/ssrn.1904072 
Hillman, A. J., Cannella, A. A., \& Paetzold, R. L. (2000). The Resource Dependence Role of Corporate Directors: Strategic Adaptation of Board Composition in Response to Environmental Change. Journal of Management Studies, 37(2), 235256. https://doi.org/10.1111/1467-6486.00179

Hillman, A. J., Shropshire, C., \& Cannella, A. A. (2007). Organizational predictors of women on corporate boards. Academy of Management Journal, 50(4), 941-952. https://doi.org/10.5465/AMJ.2007.26279222

Hoffman, L. R. (1959). Homogeneity of member personality and its effect on group problem-solving. Journal of Abnormal and Social Psychology, 58(1), 27-32. https://doi.org/10.1037/h0043499

Hoobler, J. M., Masterson, C. R., Nkomo, S. M., \& Michel, E. J. (2016). The Business Case for Women Leaders: Meta-Analysis, Research Critique, and Path Forward. Journal of Management, 44(6), 2473-2499. https://doi.org/10.1177/0149206316628643

Huse, M. (2005). Accountability and creating accountability: A framework for exploring behavioural perspectives of corporate governance. The Value Creating Board: Corporate Governance and Organizational Behaviour, 16(s1), S65-S79. https://doi.org/10.4324/9780203888711

Hussain, N., Rigoni, U., \& Orij, R. P. (2018). Corporate Governance and Sustainability Performance: Analysis of Triple Bottom Line Performance. Journal of Business Ethics, 149(2), 411-432. https://doi.org/10.1007/s10551-016-3099-5

Jensen, M. C., W. H. M. (1976). Theory of the Firm : Managerial Behavior, Agency Costs and Ownership Structure Theory of the Firm : Managerial Behavior, Agency Costs and Ownership Structure. Journal of Financial Economics. https://doi.org/http://dx.doi.org/10.1016/0304-405X(76)90026-X

Joshi, A., \& Roh, H. (2009). The role of context in work team diversity research: A meta-analytic review. Academy of Management Journal, 52(3), 599-627. https://doi.org/10.5465/AMJ.2009.41331491

Jubilee, R. V. W., Khong, R. W. L., \& Hung, W. T. (2018). Would diversified corporate boards add value? The case of banking institutions in Malaysia. Asia-Pacific Journal of Business Administration, 10(2-3), 218-228. https://doi.org/10.1108/APJBA-05-2018-0089

Klock, M. S., Mansi, S. A., \& Maxwell, W. F. (2005). Does Corporate Governance Matter to Bondholders? Bondholders ? The Journal of Financial and Quantitative Analysis, 40(4), 693-719. Retrieved from https://www.jstor.org/stable/27647221?seq=1\#page_scan_tab_contents

Konrad, A. M., Kramer, V., \& Erkut, S. (2008). Critical Mass:. The Impact of Three or More Women on Corporate Boards. Organizational Dynamics, 37(2), 145-164. https://doi.org/10.1016/j.orgdyn.2008.02.005

Labelle, R., Francoeur, C., \& Lakhal, F. (2015). To Regulate Or Not To Regulate? Early Evidence on the Means Used Around the World to Promote Gender Diversity in the Boardroom. Gender, Work and Organization, 22(4), 339-363. https://doi.org/10.1111/gwao.12091

Leuz, C., Nanda, D., \& Wysocki, P. D. (2003). Earnings management and investor protection: An international comparison. Journal of Financial Economics, 69, 505527. https://doi.org/10.4324/9780203940136

Lin, C., Ma, Y., Malatesta, P., \& Xuan, Y. (2011). Ownership structure and the cost of corporate borrowing. Journal of Financial Economics, 100(1), 1-23. 
https://doi.org/10.1016/j.jfineco.2010.10.012

Liu, Q., \& Lu, Z. (Joe). (2007). Corporate governance and earnings management in the Chinese listed companies: A tunneling perspective. Journal of Corporate Finance, 13(5), 881-906. https://doi.org/10.1016/j.jcorpfin.2007.07.003

López-Delgado, P., \& Diéguez-Soto, J. (2018). Indebtedness in family-managed firms: the moderating role of female directors on the board. Review of Managerial Science. Springer Berlin Heidelberg. https://doi.org/10.1007/s11846-018-0307-y

Low, D. C. M., Roberts, H., \& Whiting, R. H. (2015). Board gender diversity and firm performance: Empirical evidence from Hong Kong, South Korea, Malaysia and Singapore. Pacific Basin Finance Journal, 35, 381-401. https://doi.org/10.1016/j.pacfin.2015.02.008

Luo, J. hui, Huang, Z., Li, X., \& Lin, X. (2018). Are Women CEOs Valuable in Terms of Bank Loan Costs? Evidence from China. Journal of Business Ethics, 153(2), 337-355. https://doi.org/10.1007/s10551-016-3369-2

Ma, L., Ma, S., \& Tian, G. (2017). Corporate Opacity and Cost of Debt for Family Firms. European Accounting Review, 26(1), 27-59. https://doi.org/10.1080/09638180.2015.1087868

Mika, Al., \& Zumer, Ti. (2017). Indebtedness in the EU - A Drag or a Catalyst for Growth (2118). Working Paper Series. Retrieved from https://www.ecb.europa.eu/pub/pdf/scpwps/ecb.wp2118.en.pdf?42f482cdc484b29 3a3b7eb9997dfe1db

Miller, C. C., Burke, L. M., \& Glick, W. H. (1998). Cognitive diversity among upperechelon executives - implications for strategic decision processes. Strategic Management Journal, 19(1), 39-58. https://doi.org/10.1002/(SICI)10970266(199801)19:1<39::AID-SMJ932>3.0.CO;2-A

Miller, T., \& Triana, M. del C. (2009). Demographic Diversity in the Boardroom: Mediators of the Board Diversity - Firm Performance Relationship. Journal of Management Studies, 46(5), 755-786. https://doi.org/10.1111/j.14676486.2009.00839.x

Murray, A. I. (1989). Top Management Group Heterogeneity and Firm Performance. Strategic Management Journal, 10, 125-141.

Myers, S. C., \& Majluf, N. S. (1984). Corporate financing and investment decisions when firms have information that investors do not have. Journal of Financial Economics, 13(2), 187-221. Retrieved from https://www.sciencedirect.com/science/article/pii/0304405X84900230

Nielsen, S., \& Huse, M. (2010). The contribution of women on boards of directors: Going beyond the surface. Corporate Governance: An International Review, 18(2), 136-148. https://doi.org/10.1111/j.1467-8683.2010.00784.x

Omar, N. B., \& Amran, A. (2017). Corporate Governance and Climate Change Reporting in Malaysia, 7(12).

Pathan, S., \& Faff, R. (2013). Does board structure in banks really affect their performance? Journal of Banking and Finance, 37(5), 1573-1589. https://doi.org/10.1016/j.jbankfin.2012.12.016

Perryman, A. A., Fernando, G. D., \& Tripathy, A. (2016). Do gender differences persist? An examination of gender diversity on firm performance, risk, and executive compensation. Journal of Business Research, 69(2), 579-586. https://doi.org/10.1016/j.jbusres.2015.05.013

Pittman, J. A., \& Fortin, S. (2004). Auditor choice and the cost of debt capital for newly 
public firms. Journal of Accounting and Economics, 37(1), 113-136. https://doi.org/10.1016/j.jacceco.2003.06.005

Pletzer, J. L., Nikolova, R., Kedzior, K. K., \& Voelpel, S. C. (2015). Does gender matter? female representation on corporate boards and firm financial performance - A metaanalysis. PLoS ONE, 10(6), 1-20. https://doi.org/10.1371/journal.pone.0130005

Poletti-Hughes, J., \& Briano-Turrent, G. C. (2019). Gender diversity on the board of directors and corporate risk: A behavioural agency theory perspective. International Review of Financial Analysis, 62, 80-90. https://doi.org/10.1016/j.irfa.2019.02.004

Porta, R. La, Lopez-de-silanes, F., Shleifer, A., \& Vishny, R. (2000). Investor protection and corporate governance. Journal of Financial Economics, 58(1-2), 3-27. https://doi.org/10.1016/S0304-405X(00)00065-9

Post, C., \& Byron, K. (2015). Women on boards and firm financial performance: A meta-analysis. Academy of Management Journal, 58(5), 1546-1571. https://doi.org/10.5465/amj.2013.0319

Reguera-Alvarado, N., de Fuentes, P., \& Laffarga, J. (2017). Does Board Gender Diversity Influence Financial Performance? Evidence from Spain. Journal of Business Ethics, 141(2), 337-350. https://doi.org/10.1007/s10551-015-2735-9

Rossi, F., Hu, C., \& Foley, M. (2017). Women in the boardroom and corporate decisions of Italian listed companies: Does the "critical mass" matter? Management Decision, 55(7), 1578-1595. https://doi.org/10.1108/MD-01-2017-0029

Roychowdhury, S. (2006). Earnings management through real activities manipulation. Journal of Accounting and Economics, 42(3), 335-370. https://doi.org/10.1016/j.jacceco.2006.01.002

Schmitt, D. P., Realo, A., Voracek, M., \& Allik, J. (2008). Why Can't a Man Be More Like a Woman? Sex Differences in Big Five Personality Traits Across 55 Cultures. Journal of Personality and Social Psychology, 94(1), 168-182. https://doi.org/10.1037/0022-3514.94.1.168

Scholtz, H., \& Kieviet, S. (2018). The Influence Of Board Diversity On Company Performance Of South African Companies. Journal of African Business, 19(1), 105-123. https://doi.org/10.1080/15228916.2017.1356065

Sengupta Partha. (1998). Corporate the Disclosure Cost of Partha Sengupta Quality Debt and. The Accounting Review, 73(4), 459-474. https://doi.org/jstor.org/stable/248186

Sheela, S. D., Je-Yen, T., \& Rajangam, N. (2016). Board composition and corporate social responsibility in an emerging market. Corporate Governance (Bingley), 16(1), 35-53. https://doi.org/10.1108/CG-05-2015-0059

Shleifer, AndreiVishny, R. W. (1989). Management entrenchment: The case of manager-specific investments. Journal of Financial Economics, 25(1), 123-139.

Shukeri, S. N., Shin, O. W., \& Shaari, M. S. (2012). Does Board of Director's Characteristics Affect Firm Performance? Evidence from Malaysian Public Listed Companies. International Business Research, 5(9), 120-127. https://doi.org/10.5539/ibr.v5n9p120

Sila, V., Gonzalez, A., \& Hagendorff, J. (2016). Women on board: Does boardroom gender diversity affect firm risk? Journal of Corporate Finance, 36, 26-53. https://doi.org/10.1016/j.jcorpfin.2015.10.003

Singh, V., Terjesen, S., \& Vinnicombe, S. (2008). Newly appointed directors in the boardroom:. How do women and men differ? European Management Journal, 
26(1), 48-58. https://doi.org/10.1016/j.emj.2007.10.002

Singh, V., \& Vinnicombe, S. (2004). Why so Few Women Directors in Top UK Boardrooms- Evidence \& Theoretical Explanations. Corporate Governance, 12(4), 479-488. https://doi.org/10.1111/j.1467-8683.2004.00388.x

Smith, C. W., \& Warner, J. B. (1979). On financial contracting. An analysis of bond covenants. Journal of Financial Economics, 7(2), 117-161. https://doi.org/10.1016/0304-405X(79)90011-4

Smith, N., Smith, V., \& Verner, M. (2005). Do Women in Top Management Affect Firm Performance? A Panel Study of 2500 Danish Firms (No. 1708).

Smith, N., Smith, V., \& Verner, M. (2006). Do women in top management affect firm performance? A panel study of 2,500 Danish firms. International Journal of Productivity and Performance Management, 55(7), 569-593. https://doi.org/10.1108/17410400610702160

Solakoglu, M. N., \& Demir, N. (2016). The role of firm characteristics on the relationship between gender diversity and firm performance. Management Decision, 54(6), 1407-1419. https://doi.org/10.1108/MD-02-2015-0075

Srinidhi, B., Gul, F. A., \& Tsui, J. (2011). Female Directors and Earnings Quality*. Contemporary Accounting Research, 28(5), 1610-1644. https://doi.org/10.1111/j.1911-3846.2011.01071.x

Swamy, A., Knack, S., Lee, Y., \& Azfar, O. (2001). Gender and Corruption. Journal of Development Economics, 64(1), 22-25. Retrieved from https://www.sciencedirect.com/science/article/pii/S0304387800001231

Tee, C. M. (2018). Political connections, institutional monitoring and the cost of debt: evidence from Malaysian firms. International Journal of Managerial Finance, 14(2), 210-229. https://doi.org/10.1108/IJMF-07-2017-0143

Teoh, S. H., Welch, I., \& Wong, T. J. (1998). Earnings Management and the Long-Run Market Performance of Initial Public Offerings. The Journal of Finance, 53(6), 1935-1974.

Teoh, S. S. H., Welch, I., \& Wong, T. J. T. (1998). Earnings management and the underperformance of seasoned equity offerings. Journal of Financial Economics, 50(1), 63-99. https://doi.org/10.1016/S0304-405X(98)00032-4

Terjesen, S., Couto, E. B., \& Francisco, P. M. (2016). Does the presence of independent and female directors impact firm performance? A multi-country study of board diversity. Journal of Management and Governance, 20(3), 447-483. https://doi.org/10.1007/s10997-014-9307-8

Terjesen, S., Sealy, R., \& Singh, V. (2009). Women directors on corporate boards: A review and research agenda. Corporate Governance: An International Review, 17(3), 320-337. https://doi.org/10.1111/j.1467-8683.2009.00742.x

Terjesen, S., \& Singh, V. (2008). Female presence on corporate boards: A multi-country study of environmental context. Journal of Business Ethics, 83(1), 55-63. https://doi.org/10.1007/s10551-007-9656-1

Torchia, M., Calabrò, A., \& Huse, M. (2011). Women Directors on Corporate Boards: From Tokenism to Critical Mass. Journal of Business Ethics, 102(2), 299-317. https://doi.org/10.1007/s10551-011-0815-z

Usman, M., Farooq, M. U., Zhang, J., Makki, M. A. M., \& Khan, M. K. (2019). Female directors and the cost of debt: does gender diversity in the boardroom matter to lenders? Managerial Auditing Journal, 34(4), 374-392. https://doi.org/10.1108/maj-04-2018-1863 
Usman, M., Farooq, M. U., Zhang, J., Makki, M. A. M., \& Sun, J. (2019). She-E-Os and the Cost of Debt: Do Female CEOs Pay Less for Credit? B.E. Journal of Economic Analysis and Policy, 19(1), 1-7. https://doi.org/10.1515/bejeap-2018-0177

Wahid, A. S. (2018). The Effects and the Mechanisms of Board Gender Diversity: Evidence from Financial Manipulation. Journal of Business Ethics, (0123456789), 1-21. https://doi.org/10.1007/s10551-018-3785-6

Williams, R. J. (2003). Women on Corporate Boards of Directors and their Influence on Corporate Philanthropy. Journal of Business Ethics, 42(1), 1-10. https://doi.org/10.1023/A:1021626024014

Zahra, S. A., \& Pearce, J. A. (1989). Boards of Directors and Corporate Financial Performance: A Review and Integrative Model. Journal of Management, 15(2), 291-334. https://doi.org/10.1177/014920638901500208 